\title{
Dimorphococcus Fritschii, a New Colonial Protophyte from Ceylon.
}

BY

\author{
W. B. CROW.
}

With one Figure in the Text.

$T \begin{gathered}\mathrm{HE} \text { genus Dimorphococcus, A. Br., has hitherto been known to be } \\ \text { represented by two species of colonial Isokontae: }\end{gathered}$ and $D$. cordatus, Wolle. These organisms are remarkable in their method of colony formation, the four cells that are produced by division in each parent cell remaining attached for some time in groups by the agency of the parent cell membrane, which, at least in the older state, takes the form of connecting threads of mucilage. Dimorphococcus shares this type of colony formation with the genera Westella, De Wildemann, Dictyosphaerium, Ehrenb., and Radiococcus, Schmidle. Hence some authorities consider these to form a special family among the unicellular Isokontae: the Dictyosphaericeae (5). But Dimorphococcus is distinguished from these related types in a character which gives the genus its name, viz. the dimorphism of its cells.

Whilst examining specimens of plankton organisms in a collection from the inland fresh waters of Ceylon, made by Prof. F. E. Fritsch in 1903 and preserved in dilute formalin, I met with some colonies of a colonial protophyte which showed cells with a rich starch content and massive parietal chloroplast. The colony formation, moreover, was of the type mentioned above, and the dimorphism of the cells was very obvious. The organism thus had the essential characters of the genus Dimorphococcus, but further investigations showed that it differed from the two species mentioned above.

The colonies occurred in considerable quantities in the following localities: Tank ${ }^{1}$ Borlasgama, near Colombo, 8th November; tank at Kekunadure, about five miles from Matara, 8th September; canal leading from river to lake, near Bentottle, 6 th September; Lake Madampe at Ambalangodda, near the sea, I $3^{\text {th }}$ September; lake at Panadure, I6th September. The organism was not found in collections from several smaller

1 The 'tanks' in Ceylon are reservoirs of partially artificial origin. In them, however, the micro-organisms live under normal conditions.

[Annals of Botany, Vol. XXXVII. No. CXLV. January, 1923.] 
ponds that were examined, and thus appears to be chiefly a member of the limnoplankton; in this respect contrasting with D. lunatus and D.cordatus, which are members of the helioplankton. These two latter species have not yet been recorded from Ceylon.

The colonies of the new species, which may appropriately be named Dimorphococcus Fritschii, n. sp., were comparatively large, compact, compound groups. These were ellipsoidal in form, $85-100 \mu$ in length, 70-90 $\mu$ in width. Each group was composed of partial colonies of four cells each, embedded in definite colonial mucilage (see A in figure). . The cells of each partial colony were clearly dimorphous, the members of one pair being heart-shaped, the members of the alternating pair cylindric and slightly
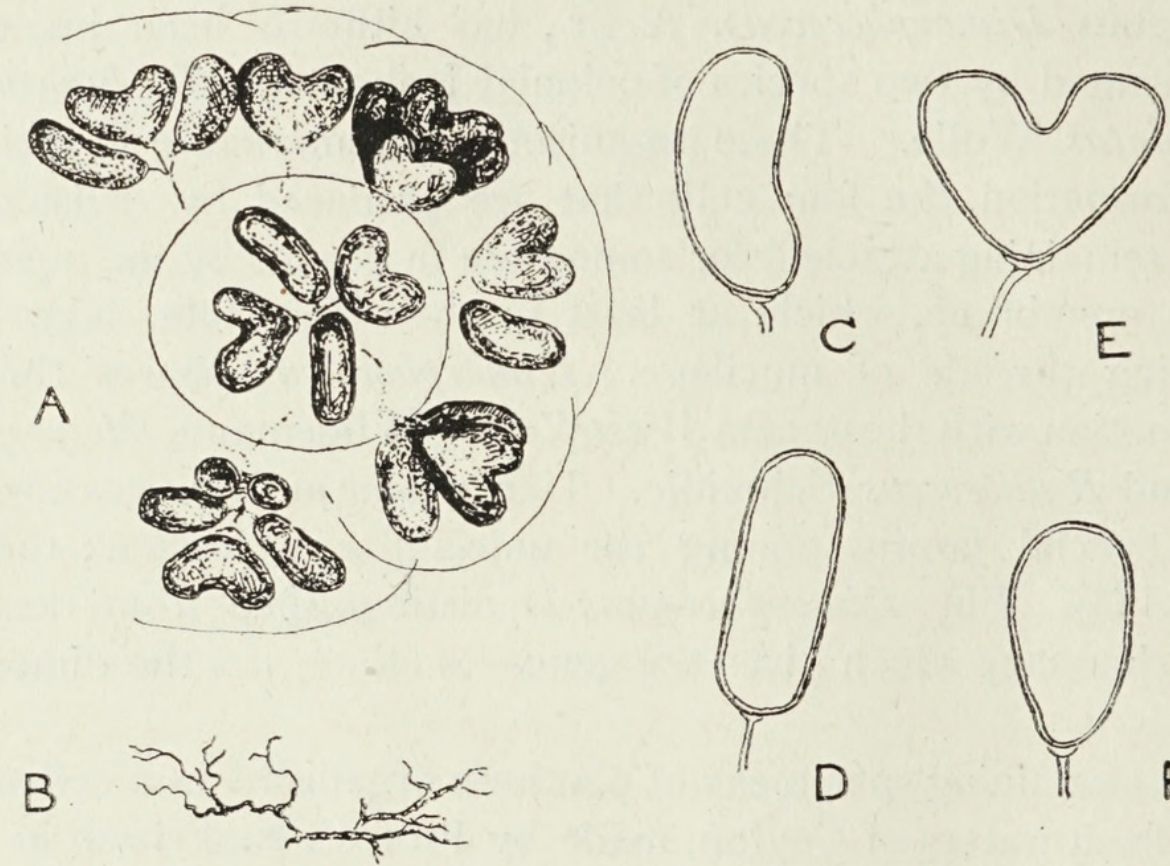

C

$E$

A. Portion of total colony. B. Portion of skeletal systems of colony dissected out. Side and front view of cylindric cell. E. and F. Side and front view of cordate cell. (Specimen from Tank Borlasgama, near Colombo.)

bent inwards. The cells were $\mathrm{I} 2-20 \mu$ in height, the width of the cylindric ones being $5^{-6 \mu}$. Each cell was borne on a short mucilage stalk and had a small lappet at its point of attachment (see $\mathrm{C}-\mathrm{F}$ in figure).

All the colonies observed were of regular ellipsoidal form ; the dimensions of the colony given above are for well-grown specimens of sixty-four to I 28 cells. From actual countings it would appear that the numbers mentioned often actually occur, i. e. the cells of a colony all belong to the same generation. This results from the fact that the cell-divisions are approximately simultaneous in all the cells of the colony, and here $D$. Fritschii may be contrasted with $D$. lunatus, A. Br. The regular form of the colonies in D. Fritschii is correlated with this fact.

There was a definite enveloping mucilage as in Dictyosphaerium. This can be seen well in glycerine jelly preparations. The presence of enveloping 
mucilage has been used by some authors to distinguish between Dictyosphaerium on the one hand and Westella and Dimorphococcus on the other (4). West (5) even divides the Dictyosphaeriaceae into two tribes on the basis of this character. Observations on the mucilage-sheath of $D$. Fritschii show that it has the same nature as that described by Senn for Dictyosphaerium pulchellum, Wood, each partial colony having its own mass of mucilage, as will be seen in our figure. The latter should be compared with that given by Senn (3). Incidentally it may be noted that the radial striations shown so prominently in some copies of Senn's figure are delicate structures which can only be seen on staining with Bismarck brown, and are invisible in the unstained condition. It is clear that the absence of a gelatinous sheath cannot be used as a generic distinction for Dimorphococcus, the essential feature of the latter genus being, of course, the dimorphism of the cells.

The partial colonies always consist of four cells each. As in the other species of Dimorphococcus, the members of each group were arranged in a manner comparable with the arrangement of the petals in a tetramerous corolla. D. Fritschii differs from D. hmatus, A. Br., in the fact that each cell has its own distinct stalk. In this respect it agrees with $D$. cordatus, Wolle, and to some extent with the species of Dictyosphaerium. The mucilage stalks of D. Fritschii are much thinner than those of D. cordatus, as figured by Chodat (2), but agree with the original of Wolle (6). They are shorter than in any Dictyosphaerium. The very peculiar thickening or lappet usually to be observed at the base of each cell, i. e. at the point where the stalk is attached, is a remarkable distinguishing feature of our species. It does not appear to be a mere thickening of the cell membrane, but rather a small segment of the mother-cell wall which has not been used up in the formation of the stalk.

In 1897 Bohlin (1) described the development of the colonies of Dimorphococcus hunatus, A. Br. He discovered that the gelatinous threads which hold the cells together are only the remains of the older membranes. Thus the colonies show a certain morphological resemblance to those of Dictyosphaerium. In the latter genus, however, the wall of the mother-cell splits into four pieces when the cell divides into four, each piece remaining attached to one of the daughter cells. In Dimorphococcus hunatus, A. Br., the daughter cells are adpressed together in tetrads; it is therefore not necessary here for each cell to have its special piece of the parent membrane, and the splitting is suppressed. Further, the walls of the mother and daughter cells do not fuse with one another, and the daughter tetrads are only fixed to the remains of the mother-cell membrane by partial gelatinization.

Bohlin does not believe that the similarity between Dimorphococcus and Dictyosphaerium indicates a near relationship between them. He points out that Zopf has shown certain morphological similarities to exist between 
Dictyosphaerium and Sciadium, yet the details of structure of the latter show it to be a genus of the Heterokontae, and the resemblance to Dictyosphaerium to rest on analogy only. In view of the differences in details of structure mentioned above, Bohlin thinks that the same applies to the supposed close relation of Dimorphococcus and Dictyosphaerium, although both, of course, must still be classed in the Isokontae.

The structure of the partial colony Dimorphococcus Fritschii, n. sp., and probably also, to a lesser extent, that of $D$. cordatus, Wolle, helps to bridge the gap between the genera Dimorphococcus and Dictyosphaerium. The fact that each cell possesses a distinct stalk, together with the character of the stalks themselves, as well as the presence of a colonial mucilage envelope in the new species, all recall the morphological features of Dictyosphaerium. Finally the presence of the small lappet at the base of each cell, if our interpretation of it is correct, shows that partitioning of the mother-cell wall into four parts is not unrepresented in Dimorphococcus, although the greater part of each segment may appear as a mucilage thong at a very early stage.

Bohlin thinks that the partial colonies of Dimorphococcus are homologous with the colonies of Scenedesmus. This is strongly supported by his description of $D$. lunatus, A. Br. In the latter the cells do not possess individual stalks, the very short strands sometimes connecting adjacent cells being comparable with the intercellular pads of some species of Scenedesmus. The four cells of the partial colony, generally closely adpressed (see e. g. 4, Pl. CXXI, Fig. 5), do not develop their corresponding mucilage thongs until they divide. For until the cells of the partial colony divide, they are enclosed in a gelatinous mass formed from the parent wall but not yet organized into thongs. Thus in comparison with Dimorphococcus Fritschii, n. sp., and the species of Dictyosphaerium, the mucilage threads of Dimorphococcus lumatus, A. Br., are late in development to the extent of one cellgeneration.

Dimorphococcus Fritschii, n. sp., appears to be closely allied to D. cordatus, Wolle.

The latter is not well known, and the figures of Chodat (2) differ remarkably from those of Wolle $(6, \mathrm{Pl}$. CLX, Figs. 30-38). It would appear that $D$. cordatus, Wolle, generally has smaller colonies than $D$. Fritschii, n. sp., is somewhat less regular in colony form, shows much less marked dimorphism in its cells, and above all lacks the colonial mucilage of our species.

In conclusion we give a diagnosis of the new organism and a summary :

\section{Dimorphococcus Fritschii, n. sp.}

Coenobio magno, ellipsoido, regulario, denso, coenobiis secondariis quaternarum cellularum compositis uniquoque certa vagina gelatinosa cir- 
cumcluso ; cellulis cuiusque coenobii secundarii bini et valde dimorphosis, his duobus cordatis, illis duobus inter haec cylindratis et paulo intus curvatis. Cellulis positis in pedunculis brevibus atque tenuibus, lasciniis parvis ad punctum ubi fixatae sunt provectis. Coenobio $85^{-100} \mu$ longo, 70$90 \mu$ lato. Cellulis $\mathrm{I} 2-20 \mu$ altis, cellulis cylindratis $5-6 \mu$ latis.

Loc. In aquis dulcibus magnis. Insula Ceylonica.

\section{SUMMARY.}

I. A new colonial member of the Isokontae, collected in the inland fresh waters of Ceylon by Prof. F. E. Fritsch, is described under the name of Dimorphococcus Fritschii, n. sp.

2. The comparative morphology and systematic relationships of the new species are discussed.

\section{LITERATURE CITED.}

1. Bohlin, K. : Die Algen der ersten Regnellschen Expedition. I. Protococcoideen. Bih. Sv. Vet. Akad. Handl., xxiii, I897.

2. Chodat, R. : Algues vertes de la Suisse, I. Berne, I902.

3. SenN, G. : Ueber einige kolonienbildende einzellige Algen. Bot. Zeit., lvii, I899.

4. Smith, G. M. : Phytoplankton of the Inland Lakes of Wisconsin, I. Wisc. Geol. and Nat. Hist. Survey, Bull. 57, I920.

5. West, G. S. : Algae, I. Camb. Bot. Handbooks, Cambridge, I9I6.

6. Wolle, F.: Freshwater Algae of the United States. Pa., I887. 


\section{$2 \mathrm{BHL}$ Biodiversity Heritage Library}

Crow, W. B. 1923. "Dimorphococcus fritschii, a new colonial protophyte from Ceylon." Annals of botany 37, 141-145.

https://doi.org/10.1093/oxfordjournals.aob.a089830.

View This Item Online: https://www.biodiversitylibrary.org/item/270686

DOI: https://doi.org/10.1093/oxfordjournals.aob.a089830

Permalink: https://www.biodiversitylibrary.org/partpdf/319073

\section{Holding Institution}

New York Botanical Garden, LuEsther T. Mertz Library

\section{Sponsored by}

BHL-SIL-FEDLINK

\section{Copyright \& Reuse}

Copyright Status: Public domain. The BHL considers that this work is no longer under copyright protection.

This document was created from content at the Biodiversity Heritage Library, the world's largest open access digital library for biodiversity literature and archives. Visit BHL at https://www.biodiversitylibrary.org. 